\title{
SEGMENTATION OF CZECH CONSUMERS BASED ON THEIR ATTITUDES TOWARDS MONEY
}

\author{
Tomek, I., Stříteský, V., Tahal, R.
}

Understanding current and potential customers' behavior is one of the key factors of marketing efficiency and it brings competitive advantage. Companies usually classify their customers and create client groups with similar characteristic features. Such grouping activity is called segmentation or typology. There are many possible methods to obtain data for the segmentation process (e.g. data mining, demographic segmentation, analyzing shopping behavior, media behavior or their combination). This paper concentrates on the financial behavior of the Czech population and brings a survey based on primary data. It takes into consideration aspects like attitude towards risk and savings and even aspects like money ethics and the role of money in society. Seven consumer segments that differ in attitudes towards money were identified and described.

JEL classification: M31

Keywords: consumer segmentation; consumer behavior; money attitudes; consumer typology

\section{Introduction}

Understanding current and potential customers' behavior is one of the key presumptions of successful business. Nowadays trends show that it may be very beneficial not only to analyze data in existing company databases but also to concentrate on consumers' individual behavior and attitudes. This paper focuses on understanding the Czech population's behavior in terms of money and their financial lives. Creating a typology of the Czech Republic's population is the key issue of this paper. Money is viewed not only as a medium of exchange but considerable attention is also put on the ethical aspects and role of money as one of the possible ways of expressing social status.

\section{Importance of the Targeting}

Being able to classify the population, getting insight into people's motivation and relationships with other people helps a lot in targeting products precisely and making marketing communication effective and not annoying. The effectiveness of the marketing communication is undoubtedly one of the most important issues that marketers and company managers deal with. The importance of marketing communication is stressed for example by Karlíček (2011, p. 20). He says that marketing communication must be primarily viewed as an investment. Financial measurement of the communication and campaign effectiveness is therefore one of the key issues. In order to use the proper communication channel and deliver an effective marketing message, it is highly important to understand consumers' preferences and classify them according to their individual nature.

Marketers across all business sectors deal with topics like brand awareness, brand recognition, customer loyalty, competitive advantage and many others. In view of these aspects, it is useful for the company to take into consideration not only the general characteristics of the population but to concentrate research activities on the specificity of the core business. It should help significantly in achieving long-term (strategic) goals. A company's customers can be classified and approached in many ways. The choice depends on the business sector that a company operates in and on the product or service features.

One of the leading business sectors where the tools of targeting and segmentation are widely used is undoubtedly the financial sector. Academic research into the possibilities of market segmentation for banks has been carried out since the early 1970s. As competition in financial services has increased, companies have 
increasingly adopted a segmentation strategy (Speed, Smith, 1992, p.369).

\section{Customer Portfolio and its Segmentation}

Different approaches can be used to classify the company's customers. Sometimes, only a single segmentation criterion is applied, but usually combinations of several criteria are used to establish easily describable and measurable client segments with internal homogeneity and external heterogeneity.

We can distinguish between four main dimensions that are, in practice, frequently used to classify and identify the customer segments.

- Mining the information from existing company databases - Such databases are usually called CRM (Customer Relationship Management databases). This approach represents a very exact method, usually based on a statistical analysis of consumers' data that have been collected. The weakness of the method is the long time span (usually several years) required for achieving precise output, and even then, we can't be sure that the types of data we store are complete. There may be even other relevant characteristics of clients, but a company does not collect and store them in the data warehouse.

- Using demographical segmentation. - Variables like gender, age or place of residence could be recognized quite easily and with almost no mistake. If the company targets a consumer group that can be characterized in this way, then demographic segmentation is the perfect tool.

- Segmentation based on consumer and media behavior - Such information can be extracted from national surveys that are almost in all countries provided by market research agencies. This kind of research is usually a part of a multinational survey that has been carried out in a large number of countries and the results are comparable. Such surveys have usually been executed as multi-client projects, meaning any client can purchase the report.

- Consumer classification may also be based on other sectoral specific criteria. In this case, a company concentrates on consumers' behavioral features that are strongly relevant and correspond with the company's business sector and with its individual strategy. It can be based on any primary data or can even be composed of several methods.

As mentioned above, the choice of segmentation criteria is predetermined by the company's strategy within a particular market sector.
Use of traditional demographic criteria is still very common. It has been used with increasing frequency in the recent period, especially in connection with Internet advertising. Thanks to new technologies, advertisers can easily identify the demographic profile of Internet users. Targeting Internet users whose demographic profile is known has become very interesting for advertisers (Stř́teský, 2011). Application of traditional demographic criteria has been verified also in specific sectors like culture (Bačuvčík, 2009).

Finding a balance between the CRM database exploration, applying lifestyle information, and analyzing typology is undoubtedly a huge challenge for the upcoming period. These activities should result in precise targeting and positioning that, in its final effect, will significantly contribute to strengthening of client loyalty.

This reopens a discussion about the slowly changing nature of the segmentation research agenda and raises questions about the ways in which research priorities are shaped by the external environment (Quinn, Dibb, 2010, p. 1239).

Once the available market data are identified, they should be applied for the purpose of marketing segmentation. It is not strictly necessary to use all the available information for segment description. Some data can be used later, operatively for tactical management. Created segments are sometime the result of marketers' best guesses and are based on their previous experience; sometimes it is the result of advanced statistical methods, such as cluster analysis, which identifies possible segments and describes their similarity and heterogeneity.

The financial sector is one of the areas where demographic segmentation is often enhanced by a consumer's typology that expresses different peoples' attitude towards risk, their lifestyle and drift.

\section{Investigating the Role of Money in Society}

Money is the accumulator of wealth. It links the present with the future. Money earned today could be invested or deposited and spent later on. An important role is played by human nature. Money can be treated very rationally, but it can also be a tool for dividing people into social groups.

There are probably two rather different fairy tales associated with money. The first one is that money and riches are just deserts for a good life. Further, this money should be enjoyed and spent wisely for the betterment of all. The other story is of the ruthless destroyer of others who sacrifices love and happiness for money (Furnham, Argyle, 1998, p. 5). 
Since ancient times, philosophers have dealt with the role of money in society. In most cases, their opinion of money is not very positive. According to Aristotle, money is a good tool for exchange of goods but if it is used for speculative purposes it spoils human character. He made a distinction between the practical and speculative points of view. A similar idea is expressed also by the Chinese philosopher Confucius who says that a noble man does not despise money but must not lose the moral value because of money.

In 1984, Furnham published his book "Money Beliefs and Behaviour Scale" where he presented the "Money Ethic Scale". This scale is the result of factor analysis and it provides six typical approaches to money.

- Factor 1: Good

- Factor 2: Evil

- Factor 3: Achievement

- Factor 4: Respect (self-esteem)

- Factor 5: Budget

- Factor 6: Freedom (power)

In his book, Furnham (1998, p. 3) points out very interesting findings. He describes how economists and psychologists differ in their professional and scientific approaches towards money. Though they share a similar goal of trying to understand and predict the way in which money is used, economists are interested in aggregated data at the macro level and are interested in modeling the behavior of prices; psychologists are more interested in understanding how and why different groups of individuals with different beliefs or different backgrounds use money differently.

\section{Methods}

Data for this study were collected through a questionnaire distributed on-line. Respondents were recruited from one of the biggest and most diverse on-line panels in the Czech Republic - Data Collect. The total size of the panel is 35000 participants. It is a representative sample of the Czech Internet population above 18 years of age. Participants are recruited through different channels (both on-line and off-line, direct mail, snow ball). The total number of respondents that were selected for this study was 607. Stratified probability sampling method was used. Strata were defined according to the place of residence, education, age and gender.

The segmentation process in this study is based on the standard approach (e.g. Dillon, Madden, Firtle, 1993). Collected data were analyzed through factor analysis. Factor analysis was used to find latent variables (factors) explaining several variables measured. In the next step, respondents were assigned to the uncovered segments and finally, segments were described based on socio-demographic, behavioral and lifestyle characteristics. The segmentation method used is not disjunctive, meaning that uncovered segments do not have empty intersections. The sum of the persons belonging to the individual segments thus exceeds $100 \%$. This approach is not so common, but we think that it better reflects the reality on the market. In other words, we measured an inclination of each respondent to individual segments.

In the first step of the analyses we created factors through factor analysis to identify the number of consumer types in the Czech financial market. We used a Pearson correlation with a 2-tailed test of significance. Principal component analysis was used as an extraction method. There are several possibilities how many factors to extract. Common methods are mechanical ones, e.g. all factors with eigenvalues greater than 1 or all factors with non-negative eigenvalues. In this study the non-mechanical method was used. We gradually extracted 5, 6, and 7 factors to identify how many types of consumers in the Czech population exist. We also assessed discriminant validity of the factors through the method described by Fornell and Larcker (1981). We found out that seven factors are best fitting to the current Czech situation.

In the second step, we created factor scores to get information about individuals' placement on the factor distribution. We used these scores for determining the degree of individual inclination of each respondent to each type of behavior (i.e. to all seven uncovered segments). We based our approach on the assumption that belonging to a segment is not a binomial variable but rather a continuous variable which is approximated by these scores.

Consequently, it was necessary to determine the limits of score values from which the acceptance rate of the respondent would be considered as belonging to a particular segment, only partially affected by the segment or finally, when we mark the respondent as unaffected, i.e. with a low rate of inclination to the segment. To do this, it is possible to use a variety of methods, such as quartiles, deciles, or other measures of the position where the upper quartile will always be considered as representative of a certain segment. However, we prefer a different methodology, which is not, as above, mechanical. For that, we used other variables that were examined in the research and were not included in the formation of segments but we know their expected affinity for certain patterns of behavior. In the next step, cluster analysis was used (Ward's method) and thus we examined similarity of respondents with certain summed factor score levels in those variables. In other words, we clustered 
distributions of the responses and determined the limits of the summed factor score for belonging to the individual segments at the value where the biggest differences occurred. These limits of summed factor score defined the categories of each output variable (factor), i.e. segment boundaries.

\section{Results}

As described in the methodology chapter, through factor analysis we uncovered seven segments (consumer types) based on consumer attitudes towards money and the perception of its role in human life. Market segments and their size within the Czech population are presented in Table 1.

Table 1: Consumer segments and their size within the Czech population

\begin{tabular}{|l|c|}
\hline Market segments & $\begin{array}{c}\text { Market segment size } \\
\text { (\% of Czech population) }\end{array}$ \\
\hline Rational & $27.3 \%$ \\
\hline Timid & $23.5 \%$ \\
\hline Scrooge & $22.3 \%$ \\
\hline Spender & $12.8 \%$ \\
\hline Saint & $11.2 \%$ \\
\hline Refusing - Money is Evil & $10.8 \%$ \\
\hline Worshipper - Money is Everything & $10.2 \%$ \\
\hline Total & $118.1 \%$ \\
\hline
\end{tabular}

Source: authors, $\mathrm{N}=607$

A method of overlapping (fuzzy) segmentation was used, meaning that some consumers may belong to multiple market segments (Koudelka, 2005). The total sum in Table 1 thus exceeds $100 \%$. The uncovered segments (consumer types) are described in the following chapters.

\section{Rational}

Rational consumers represent the largest segment of the Czech market (27.3\% of Czech consumers strongly tend to this type). They regard money as important but they do not worship it as they know that other things are more important in their lives. The rational type is cautious, carefully plans their expenditures, works to earn money but he/she can also enjoy money and buy something just for fun. Generally, consumers from this segment do not buy anything to show off their wealth. Examples of scale statements with highest factor loadings are as follows:

- "I know exactly how much I pay for rent, gas and electricity" (0.579).

- "Usually, I know exactly how much money I have in my bank account" (0.537).
- "I work hard to earn lots of money" (0.459).

- "I think carefully about what I will do with my money" (0.419).

This segment is relatively balanced by gender; male consumers slightly exceed female consumers ( $30.0 \%$ male respondents, $24.7 \%$ female respondents). Consumers are mostly middle aged and with rather higher income.

\section{Timid}

This type of consumer is also fairly widely represented on the Czech market (23.5\%). As for money, these consumers are distrustful of others. They believe that money degrades human relations. They reject loans because they think that loans lead people to debt. If they find something for a cheaper price than they bought it for, they grieve over it. They also feel regret money spent on fees for foreign ATM withdrawals. They want to save money for a rainy day. Typical opinions of this segment are represented by the following statements with relatively high factor loadings:

- "When I buy something and then I find it cheaper elsewhere, I grieve over it" (0.491).

- "One should have saved money for a rainy day" (0.484).

- "Money gives people power over others" (0.449).

- "Money spoils human relationships" (0.428).

This segment consists more of female consumers than males ones; age groups are equally represented. Lower income and completed education are typical for this segment.

\section{Scrooge}

This is a segment from the "Big Three". Over one fifth of the Czech population tend to this consumer profile. Scrooge knows how to save money. He/she plans and monitors his/her spending. He/she spends only what is needed. Consumers from this segment characterize their financial situation as quite good in comparison with others, but are the type of people who do not show off their wealth. They do not enjoy money nor does buying things bring them pleasure. They do not have dreams about what they would buy if they won the lottery. "Loan" is an ugly word for them.

This consumer segment is characterized by the following attitudes towards money:

- "I think I can save money" (0.724).

- "I carefully plan my expenses" (0.679).

- "I carefully think about how to spend my money usefully" (0.609). 
- "I am better with money than people around me think" (0.365).

Scrooge is a segment where female and male consumers are represented equally. As to the age of the consumers, similar findings were observed. Both lower and upper income groups are represented in this segment; however, the middle income group is rarely seen.

\section{Spender}

Spender is the opposite of Scrooge. Shopping makes him/ her happy and sometimes he/she even buys something that he/she cannot afford. Spenders like to show off their wealth. They like it when people can see that they have enough money. They often buy expensive things to make people envious of them. The spending of this consumer segment is not overly planned. Spenders do not care much about loans or even about laws when money is in the game. This consumer segment can be characterized by the following statements with a strong agreement:

- "Sometimes I buy things to make an impression on others" $(0,703)$.

- "It is better if my friends think I have enough money, than vice versa" (0.490).

- "I am better with money than people around me think" (0.490).

- "Buying what I want makes me happy" (0.374).

- "Sometimes I buy a thing that I basically cannot afford" (0.358).

This segment covers $15 \%$ of male and $11 \%$ of female consumers. Spenders are mostly young people $(25 \%$ respondents up to 25 years old belong to this segment) across all education levels with middle and higher incomes. This type of consumer lives mainly in big cities.

\section{Saint}

This type of consumer perceives money as a gift that people should share with those who have little and need it. He/she trusts people. He/she thinks that the world would be better without money and it is not all right when people have more than they need. Saint consumers would not infringe laws for money.

Consumers from the segment strongly agree with the following statements that represent their attitudes and opinions:

- "It is correct to give some of my money to those who are less fortunate" $(0.823)$.

- "Money is a gift and we should share it with needy people" (0.780).

- "The world would be a better place without money" (0.290).
Saints also believe that it is not right to have more money than one needs, but with relatively low factor loading 0.214 . They are rather ideological people, a market segment with no defined socio-demographic profile. Female consumers with lower income slightly prevail but generally, this small segment consists of consumers with different socio-demographic characteristics.

\section{Money is Evil}

This consumer believes money to be something that does not bring happiness and spoils human relationships. He/ she even personally does not want more money than he/she really needs. Generally, a consumer from this segment does not care about money. Shopping does not bring him/her pleasure. He/she is worried about loans as he/she believes they lead people to debt.

The segment's attitudes towards money can be clearly expressed by several research statements with relatively high factor loadings:

- "Rich people are not happy" (0.676).

- "Rich people have very few friends" (0.631).

- "It is not right to have more money than one needs" (0.620).

- "I don't care much about money. Sufficient unto the day is the evil thereof." (0.548).

- "Money spoils human relationships" (0.506).

- "I need only as much money as it is necessary for life" (0.457).

- "The world would be a better place without money" (0.412).

Money is considered as evil more often by men than women. Both young and old consumers comprise the segment; middle-aged consumers do not hold these opinions. Consumers from this segment have lower incomes and educational levels. They come both from rural areas and big cities.

\section{Money is Everything}

Consumers from this segment wish to have a lot of money. They dream about what they would buy if they were very rich. Sometimes they are even negligent of their family when earning their money. They believe that money brings happiness and power as well as increases the respect of others. Consumers from this segment admire rich people. They buy expensive things to show off their wealth.

Characteristic opinions and attitudes of this segment are evident from the scale statements with a relatively high factor loading: 
- "It is hard to be happy when one has little money" (0.680).

- “Money gives meaning to life" (0.673).

- "The one who has money is the one who is respected by others" (0.560).

- "I admire people who have more money than I do" (0.553).

- "Money is never enough" (0.490).

- "Sometimes, I don't have enough time for my family or personal life because of making money" (0.425).

- "I would probably not always follow the law if it were about to get a lot of money" (0.385).

- "It's all right to borrow money for what I want" (0.375).

This consumer segment is formed by young people (it covers $15 \%$ of consumers up to 24 years of age). In this group, consumers with an elementary education level, living in towns and cities, prevail. There are no systematic differences by income; there is a slightly stronger representation of this profile among consumers with lower incomes.

\section{Managerial Implications}

Consumers differ in their behavior and therefore businesses cannot use one marketing mix for the whole market but rather separate mixes for different segments of the market. Finding the right target population for the company's communication and product targeting helps a lot to increase awareness and bring the desired ROI. To achieve this goal, marketers should focus on what consumers think, how they behave and what is their attitude towards interpersonal relationships. Consumer typologies help to understand the consumption patterns of the consumers and allow marketers to customize their communication activities. The research based on primary data has resulted in establishing the topical classification of the population of the Czech Republic in relation to money and financial behavior. Seven consumer segments that differ in attitudes towards money were identified and described. Combining the attitude towards money with socio-demographical characteristics suggests the possibility of further marketing use, both in academic exploration and in professional banking. Since there are no current research studies published concerning money attitudes of Czech consumers, the presented results make a significant contribution to understanding of their financial behavior. This knowledge is very useful not only for business from the financial sector as money attitudes influence the buying decision making process of consumers generally. Uncovered consumer segments offer a solid base for managerial decisions concerning the strategy of target marketing.

\section{References}

Bačuvčík, R. (2009). Kultura a my: vztahy na poptávkové straně trhů kulturních produktů. Zlín: VeRBuM.

Dillon, W.R., Madden, E. I., Firtle, N. H. (1993). Marketing Research in a Marketing Environment. Homewood, IL: Irwin, Third Edition.

Fornell, C., Larcker, D. F. (1981). Evaluating structural equation models with unobservable variables and measurement error. Journal of Marketing Research, 18 (1): 39-50.

Furnham, D., Argyle, M. (1998). The Psychology of Money. London: Routledge.

Karlíček, M., Král, P. (2011). Marketingová komunikace. Prague: Grada Publishing.

Koudelka, J. (2005). Segmentujeme spotřebni trhy. Prague: Professional Publishing.

Quinn, L., Dibb, S. (2010). Evaluating market-segmentation research priorities: Targeting re-emancipation. Journal of Marketing Management, 26 (13): 1239-1255.

Speed, R., Smith, G. (1992). Retail Financial Services Segmentation. The Service Industries Journal, 12 (3): 368-383

Stříteský, V. (2011). Možnosti demografické segmentace při cílení reklamy na internet, in Tradiční a nové v marketingové komunikaci, ed. Bačuvčík, R. et al., Zlín : VeRBuM, 165-172.

Authors

RNDr. Ivan Tomek, CSc.

Owner of consulting agency Mr. Think Moravska 45, 12000, Prague, Czech Republic ivan.tomek@mrthink.cz

Ing. Václav Střiteský, Ph.D.

Assistant Professor Department of Marketing, Faculty of Business Administration, University of Economics, Prague W. Churchill Sq. 4, 13067 Prague, Czech Republic vaclav.stritesky@vse.cz

Mgr. Radek Tahal, Ph.D.

Assistant Professor

Department of Marketing, Faculty of Business Administration, University of Economics, Prague W. Churchill Sq. 4, 13067 Prague, Czech Republic radek.tahal@vse.cz

The study was supported from the resources for longterm conceptual research development of the University of Economics, Prague (IP300040). 